\title{
The effectiveness of community participation in planning and urban development
}

\author{
C. van Empel \\ Christchurch Polytechnic Institute of Technology, New Zealand
}

\begin{abstract}
Contemporary planning theories acknowledge the value of community participation in the development processes of our built environment, suggesting that community involvement has the potential to achieve a more sustainable outcome. Research in this field indicates that citizen participation can generate trust, credibility and commitment regarding the implementation of policies.

This paper investigates tools to measure the effectiveness of public participation and their influence on urban development processes. Based on a literature review, a framework of indicators was developed, which has been used to analyse the community participation process in the development of the 'Greater Christchurch Urban Development Strategy', a collaborative initiative to develop a growth strategy for the Christchurch region in New Zealand.

Results from this case study suggest that there is a relationship between the various indicators and the main findings can be summarized as follows: (i) Most sectors of the community appear to have an interest in their built environment and urban planning processes, provided that their involvement is encouraged by stimulating information and expertise is provided to support their contributions. (ii) Although no conclusions on the motivation of the various participants in the process were reached, the professionals involved appear to have a strong interest in networking and the sharing of expertise. (iii) A commonality in the views of the public was observed, with a focus on the 'big picture' rather than selfinterests. (iv) Collaborative planning was experienced as an effective technique for consensus building between professionals. (v) The quality of resources and allocation of time appear to be influential in a community participation process. (vi) Indications were given that process and product outcomes should not be evaluated separately.
\end{abstract}

Keywords: community participation, collaborative planning, urban development, public consultation. 


\section{Introduction}

\subsection{Background}

Contemporary planning theories acknowledge the value of community participation in the development processes of our built environment, suggesting that community involvement has the potential to achieve a more sustainable outcome. Planning scholars such as Brody et al. [1] have argued that citizen participation can generate trust, credibility and commitment regarding the implementation of policies. Earlier research by Moote et al. [2] suggested that one of the characteristics of a participatory democracy is that conflicts are resolved during the planning process rather than delaying the implementation of completed plans.

However, despite recognition of the value of community input into planning processes, the effect that public involvement has on urban developments seems to be experienced in a variety of ways. An explanation for this diversity in the perception of community participation might be found in the different views on community participation approaches, as identified by Bishop [3]. This observation implies that having the community involved in the process is no guarantee in itself of successful public influence on outcomes.

To analyse the effectiveness of a participation process it is useful to evaluate the process against the 'ladder of participation' as identified by Arnstein [4]. She linked the form of participation to the level of delegation, by constructing a scale from "citizen control" as a degree of citizen power at one end of the scale to "manipulation" as non-participation at the other end. Most significant in this respect is that "consultation", as the most commonly used term for participation, is located in the mid range of this table, suggesting the limited influences the public might have on the processes. This observation supports the need to investigate available tools for the measurement of the effectiveness of public participation and its influence on urban development and planning processes.

\subsection{Research objectives and methodology}

The main objective of this investigation was to assess the effectiveness of a participation process used in planning and urban development. In order to achieve the objectives of this study, the following key issues were considered significant in the evaluation of the effectiveness of community involvement:

1. Identify the interested parties and their motivations for participation.

a) Who are the participants and what is their motivation to participate?

b) Can we establish the "representative-ness" of the participants?

2. Identify the conflicts of interests of the various participants in the process.

a) Are there any conflicts of interest among the various participants?

b) Is the interest based on 'self-interest'?

3. Evaluate the participants' satisfaction levels in relation to their objectives.

a) Are all participants satisfied with the process, either by recognising their own input or by appreciating other views / arguments?

b) Can we recognise a sense of 'ownership' within the community? 
4. Evaluate the conditions set for the community involvement process.

a) Was the community well informed (e.g. sufficient resources)?

b) Was there access to (independent) professional support for the community?

The research approach was based on a qualitative research strategy, by identifying existing participation techniques in planning processes and examining the characteristics of these techniques through a literature review. The findings were used to develop a framework of evaluative indicators for the investigation of the effectiveness of community involvement in urban developments, by way of a case study, using observation and analysis of available data.

Further information was obtained through a questionnaire survey, which was conducted using a small sample representing a balanced cross-section of the identified key stakeholders in the process.

\section{Literature review}

On reviewing the literature various views on community participation were found where the values of public participation were widely acknowledged and the objectives of community involvement clearly identified. However the issue of how to measure the effectiveness of public participation has been covered to a lesser extent. In this context effectiveness was defined as the achievement of objectives with a focus on the development of mutually acceptable solutions and its contribution to the quality of the final outcome.

The objectives of this study were to identify the various community participation techniques and their specific characteristics, and to investigate the importance of community involvement and its implications for the process.

The literature review showed that most researchers in environmental planning related fields have made a distinction between participation 'process' and 'product outcomes'.

In this paper a set of evaluative indicators for the participation 'process' have been extracted from the literature review, which have been considered useful as a framework for a case study analysis. An overview of the indicators identified by the various scholars is shown in Table 1.

It should be noted that the developed framework of indicators for effectiveness of public participation are 'process' orientated. Although for the analysis of the effectiveness of community participation the distinction between process and outcome might be useful, Innes and Booher [10] suggested that process and outcomes should not be separated. They observed that no matter how good an agreement is, if it was based on a process that was not regarded as fair, open, inclusive, accountable or otherwise legitimate, it is unlikely to receive support. This theory suggests that the findings from the indicators for the 'process' might hold some valuable clues for the effectiveness of the product outcomes. 
Table 1: Matrix summarizing the 'effectiveness' indicators identified in the literature review.

\begin{tabular}{|c|c|c|c|c|c|c|c|c|}
\hline $\begin{array}{l}\text { Researchers } \\
\text { (from literature } \\
\text { review) }\end{array}$ & $\begin{array}{c}\exists \\
\Xi \\
\dot{\pi} \\
0 \\
0 \\
3 \\
0 \\
0 \\
0\end{array}$ & 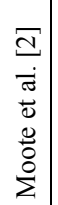 & 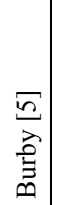 & $\begin{array}{l}\sigma \\
\bar{\sigma} \\
\overline{0} \\
0\end{array}$ & 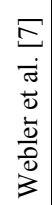 & 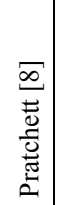 & के & \\
\hline Indicators & & & & & & & & $\begin{array}{l}\text { Issues to be } \begin{array}{l}\text { investigated } \\
\text { measurement for 'effectiveness' }\end{array} \text { as a } \\
\end{array}$ \\
\hline Administration & $\mathrm{x}$ & & $\mathrm{x}$ & & & & & $\begin{array}{l}\text { To confirm that an appropriate timeline } \\
\text { and resources have been allocated to } \\
\text { support the process }\end{array}$ \\
\hline Objectives & $\mathrm{x}$ & & $\mathrm{x}$ & & & & & $\begin{array}{l}\text { To establish the expected level of } \\
\text { participation in relation to the objectives } \\
\text { of the participants, ranging from } \\
\text { compliance with regulatory requirements } \\
\text { to engaging citizens in decision-making }\end{array}$ \\
\hline Stage & $\mathrm{x}$ & & $\mathrm{x}$ & & & & & $\begin{array}{l}\text { To identify the timing of the participation } \\
\text { process in relation to the decision making }\end{array}$ \\
\hline Targeting & $\mathrm{x}$ & & $\mathrm{x}$ & & & & & $\begin{array}{l}\text { To identify the potential stakeholders and } \\
\text { the selected participants in the process, by } \\
\text { invitation and otherwise }\end{array}$ \\
\hline Technique & $\mathrm{x}$ & & $\mathrm{x}$ & & & & & $\begin{array}{l}\text { To identify the various types of } \\
\text { involvement chosen to engage the } \\
\text { community in the process }\end{array}$ \\
\hline Information & $\mathrm{x}$ & & $\mathrm{x}$ & & & & & $\begin{array}{l}\text { To establish the quality / relevancy of the } \\
\text { exchanged information and the continuity } \\
\text { of dialogue between the parties }\end{array}$ \\
\hline Legitimacy & & & & & $\mathrm{x}$ & & & $\begin{array}{l}\text { To establish that the participant's input is } \\
\text { acknowledged and respected }\end{array}$ \\
\hline $\begin{array}{l}\text { Ideology } \\
\text { Values }\end{array}$ & & $\mathrm{x}$ & & $\mathrm{x}$ & $\mathrm{x}$ & & & $\begin{array}{l}\text { To identify the different viewpoints of the } \\
\text { participants and to confirm a mutual } \\
\text { understanding through dialogue }\end{array}$ \\
\hline $\begin{array}{l}\text { Fairness } \\
\text { Equality }\end{array}$ & & & & $\mathrm{x}$ & $\mathrm{x}$ & & $\mathrm{x}$ & $\begin{array}{l}\text { To establish the quality of interactions, } \\
\text { trust and achieved consensus }\end{array}$ \\
\hline Equal power & & & & & $\mathrm{x}$ & & & $\begin{array}{l}\text { To establish an open process, with equal } \\
\text { opportunities for all participants }\end{array}$ \\
\hline Leadership & & & & & $\mathrm{x}$ & & & $\begin{array}{l}\text { To identify an effective decision-making } \\
\text { process based on submitted evidence }\end{array}$ \\
\hline Competence & & & & & $\mathrm{x}$ & & $\mathrm{x}$ & $\begin{array}{l}\text { To encourage participants to gain new } \\
\text { knowledge and to establish that required } \\
\text { information and expertise is available }\end{array}$ \\
\hline Social learning & & $\mathrm{x}$ & & $\mathrm{x}$ & $\mathrm{x}$ & & $\mathrm{x}$ & $\begin{array}{l}\text { To contribute to an understanding of } \\
\text { concerns and values of other participants }\end{array}$ \\
\hline Efficacy & & $\mathrm{x}$ & & & & & & $\begin{array}{l}\text { To establish the participant's level of } \\
\text { acceptance, beneficial for implementation }\end{array}$ \\
\hline Responsiveness & & & & & & $\mathrm{x}$ & & $\begin{array}{l}\text { To establish the extent to which decision- } \\
\text { makers take note of the participants' views }\end{array}$ \\
\hline $\begin{array}{l}\text { Representative- } \\
\text { ness }\end{array}$ & & $\mathrm{x}$ & & & & $\mathrm{x}$ & & $\begin{array}{l}\text { To establish the extent to which the } \\
\text { participants have resources and skills }\end{array}$ \\
\hline Capacity & & & & & & & $\mathrm{x}$ & $\begin{array}{l}\text { To identify the conditions and } \\
\text { opportunities for the parties to participate }\end{array}$ \\
\hline Willingness & & & & & & & $\mathrm{x}$ & To establish the motivation to participate \\
\hline
\end{tabular}




\section{Case study - growth strategy for Christchurch (NZ)}

\subsection{Scope/context}

The Greater Christchurch Urban Development Strategy (GCUDS) project is a collaborative initiative between Christchurch City Council (including Banks Peninsula), Selwyn and Waimakariri District Councils, Environment Canterbury as the Regional Council, Transit New Zealand and community and business stakeholders. The aim of the project is to develop a strategy for the expected population growth over the next $20-40$ years in the Greater Christchurch area. The following components have been identified in the Community Communication and Consultation process and the staging of the project:

a) Issues Awareness.

The objectives of the first part of the consultation process were twofold; firstly, to inform the public of the issues related to the expected future population growth in the Greater Christchurch area and secondly, to develop public interest in the topics to create a basis for further community involvement.

b) Options Consultation.

For the second part of the consultation process an 'Options' document [11] was developed to encourage public debate and community participation in the process through submissions on the various issues related to the expected growth in the Greater Christchurch area.

c) Community Charter.

From the community feedback in the first stages of consultation 'Key Outcomes and Objectives' were acknowledged and published in a Community Charter [12], which was used as a framework for the development of the Draft Strategy.

d) Inquiry by Design workshops.

To support the development of a Draft Strategy document, technical workshops, using a collaborative planning approach, were organised for the visualisation of the objectives from the Community Charter.

e) Draft Strategy Consultation.

Following the development of a Draft Strategy, a further consultation process with the community will be established. During this stage the community will be presented with the draft document and will be invited to participate in the process through submissions and hearings in order to finalise the Strategy for adoption and implementation.

\subsection{Analysis of case study}

The analysis of the case study has shown that the initiators of the project have acknowledged the indicators identified by Brody et al. [1] and Burby [5] and that these indicators have the potential to influence the participation process. The techniques, timing and resources used in the first stages of consultation have been experienced as being supportive in the communication process. The development of a Community Charter, which was used as a framework for the development of the Draft Strategy, suggests an acknowledgement of the 
relevancy of community involvement in relation to the decision-making points and seems to satisfy the objectives for public participation beyond a compliance with the regulatory requirements. Challenges have been experienced regarding the representation of some interest groups in the process and the continuity of the information stream and public involvement during the later stages of the development of a Draft Strategy document.

The analysis has also shown the relevancy of the indicators to measuring the effectiveness of a participation process as identified by other studies [2, 6-9] and has suggested that some inter-relationships between the various indicators might exist. The adoption of the Community Charter has been seen as one of the ingredients of a legitimate process and has indicated respect for the community input. The collaborative planning approach in the Inquiry by Design workshops have been experienced as being beneficial for the development of a mutual understanding of the issues at hand and have contributed to trust and consensus building between the participants. To what extent the participants have had equal opportunities to participate has been under scrutiny and whether the elected members of participating Councils can represent the community at large in planning processes is a matter of debate. The case study has shown a genuine interest in urban development issues and has indicated a high level of motivation in the community to participate in the process.

\section{Evaluation and conclusion}

As presented in the Introduction, the main objective of this research was to investigate tools to measure the effectiveness of the participation processes used in planning and urban development and to what extent they are influencing the outcomes. The indicators for evaluating 'effectiveness' as extracted from the literature review have proved valuable for identifying which factors are influencing the process and eventually the outcome of this case study. The case study has shown, however, that although the use of the individual indicators was beneficial for the analysis of the process, the identified indicators are related and influence each other, suggesting that they should not be evaluated independently.

With regard to the factors influencing the participation process, the case study has revealed the following findings: (i) The expected level of participation is strongly related to the objectives for being involved in the process and appropriate participation techniques should be selected to accommodate these objectives. The staging of community involvement should also be evaluated in connection with the objectives. ii) The capacity of the participants to contribute to the process should not be evaluated in isolation, as the other indicators such as representative-ness, fairness and equal power might have an influence on this indicator. (iii) Fairness of the process and equal power of the participants are influencing factors for the assessment of the responsiveness of the process. The interrelationship between the various indicators becomes further evident as responsiveness of the process might contribute to the validity of the product outcome. (iv) On the distinction between 'process' and 'product outcome' related factors the case study has shown a strong support for the findings of 
Innes and Booher [4] that for the analysis of the effectiveness of community participation, process and product outcome should not be separated. Due to the timeline for the case study only the process was evaluated, however, there are strong indications that the factors in the process will have an influence on the final product outcomes.

Based on the indicators used in the case study to measure the effectiveness of the community involvement in the process, the findings of this research can be summarised by addressing the key issues as identified in the Introduction as follows:

\section{Identify the interested parties and their motivations for participation.}

The case study has shown that most sectors of the community seem to have an interest in their built environment and associated urban planning processes, provided that their involvement is encouraged by stimulating information on the relevant issues and expertise is provided to support their contributions. This research has not reached any firm conclusions with regard to the motivation of the various participants in the process, apart from the professionals involved in the project having an interest focused on networking and expertise.

2. Identify the conflicts of interests of the various participants in the process.

The first community consultation stages of the case study indicated unexpected common views from the public, with a focus on the 'big picture' rather than self-interests. Whether the resources made available at the time might have influenced such an outcome remains unanswered.

Another observation has been made in the Inquiry by Design workshops, confirming that the used collaborative planning approach was experienced as an effective method for consensus building between the professionals involved.

3. Evaluate the participants' satisfaction levels in relation to their objectives.

To establish the satisfaction levels of the participants and the sense of 'ownership' within the community, further research is required throughout the implementation stages of the project. As mentioned above the urban design workshops have contributed to appreciation and mutual understanding between the various disciplines.

4. Evaluate the conditions set for the community involvement process.

The available resources in the case study appear to have been very supportive of the community participation process. In this respect two observations should be noted however; firstly suggestions have been made that the information package to the public in the early stages of the project might have contained some directive material influencing public opinion. Secondly concerns have been expressed that time restrictions due to the set target date for the implementation of the Strategy might have compromised the community participation process.

This study has found that measuring the effectiveness of participation processes in planning and urban development should not be based on individual indicators as found in the literature in isolation, as they have the potential to influence each other. There are also strong indications that community 
involvement in these processes is highly valued, supporting the findings of Bishop [3] that people want a direct say, not filtered through elected representatives. Although due to the timeline of the case study, the research was limited to the community participation process related indicators, the observation of the process has supported the suggestion by Innes \& Booher [4] that process and outcomes should not be separated and that the conditions created for the participation process might have an influence on the final product outcomes. Further research to assess the influence of community involvement on the product outcomes would therefore be valuable.

\section{References}

[1] Brody, S.D., Godschalk, D.R., \& Burby, R.J., Mandating citizen participation in plan making: six strategic planning choices, Journal of the American Planning Association, Vol. 69 i3 p 245 (20), 2003

[2] Moote, M.A., Mcclaran, M.P. \& Chickering, D. K., Theory in Practice: Applying Participatory Democracy Theory to Public Land Planning, Environmental Management, Vol. 21, No 6, pp. 877-889, 1997

[3] Bishop, P., Mapping Public Participation in Policy Choices Australian Journal of public Administration, Vol. 61 (1): 14-29, 2002

[4] ARNSTEIN, S, A ladder of Citizen Participation, Journal of the American Institute of Planners 35(4): 216-24, 1969

[5] Burby, R.J., Making Plans that Matter: Citizen Involvement and Government Action, Journal of the American Planning Association, Vol. 69, 33-49, 2003

[6] Todd, S., Measuring the effectiveness of environmental dispute settlement efforts, Environmental Impact Assessment review 21: 97-110, 2001

[7] Webler, T., Tuler, S. \& Krueger, R., What is Good Public Participation Process? Five Perspectives from the Public, Environmental Management, Vol. 27 No 3 pp. 435-450, 2001

[8] Pratchett, L., New Fashions in public Participation: Towards Greater Democracy? Parliamentary Affairs 52: 616-34, 1999

[9] Palerm, J.R., An Empirical-Theoretical Analysis Framework for Public Participation in Environmental Impact Assessment, Journal of Environmental Planning and Management, 43(5): 581-600, 2000

[10] Innes, J.E., \& Booher, D.E., Consensus Building and Complex Adaptive Systems: A Framework for Evaluating Collaborative Planning, Journal of the American Planning Association, Vol. 65: i4 p 412, 1999

[11] Greater Christchurch Urban Development Strategy, So many options...which will you choose? April 2005.

[12] Greater Christchurch Urban Development Strategy, Community Charter, March 2006. 